\title{
Teacher's Creativity in the Development of Learning Media Fun Book in Kindergarten
}

\author{
Indri Dwi Isnaini ${ }^{1 *}$, Mira Pradipta Ariyanti ${ }^{1}$
}

\author{
${ }^{I}$ STKIP Bina Insan Mandiri Surabaya \\ "Corresponding author. Email:indridwi@ stkipbim.ac.id
}

\begin{abstract}
Creativity is all activities that bring results that are innovative, useful, and easy to understand. It's very important to have a teacher, especially for kindergarten teachers. Because young children get bored easily and are always interested in new things. This study aims to describe the creativity of teachers in developing learning media Fun Book Learning in Kindergarten Dharmawanita Gedangan Kutorejo Mojokerto. The research method used was a qualitative research method. The subjects of this study were 3 teachers. Data collection techniques were obtained from interviews, observations and documentation. Data analysis was performed using Miles and Huberman analysis with three steps - the first step was data reduction, the second was data presentation and the third was verification or conclusions. Test the validity of the data in this study was carried out with the triangulation technique that is utilizing something other than data for comparative purposes data. Based on the results of data analysis shows that the three teachers at the Dharmawanita Gedangan Kindergarten can be said to be creative teachers, because they already have four aspects of creativity, namely fluency in thinking, flexibility, originality, and elaboration. Viewed from the four aspects, his enthusiasm and enthusiasm in developing Fun Book Learning media. They combine from pre-existing media, then all activities are adjusted to the development achievements of children aged 4-5 years of the 2013 curriculum. All of that is done so that their students can get innovative and fun media.
\end{abstract}

Keywords: Teacher Creativity, Fun Learning Media Books

\section{INTRODUCTION}

The teacher is a leader in learning in school. As a learning leader, the teacher has full responsibility for learning activities. The teacher must be able to design, implement, and of course evaluate learning practices effectively. Able to develop learning media so that children are not easily bored with learning. For this reason the teacher must be creative, because the teacher's creativity will determine the success or failure of learning in school. James J. Gallagher (in Rachmawati, 2011: 13) says that creativity is a mental process carried out by individuals in the form of new ideas or products, or combining between the two that will eventually be attached to it. Santrock (2008: 324) argues that creativity is the ability to think in new and unusual ways and produce unique problem solving.

The creative potential of the teacher will develop and develop in an interactive and appreciative atmosphere. In learning children's understanding is greatly influenced by the creativity of a teacher, because the more teachers are creative in terms of learning or delivery of material, the easier it is for children to understand the lessons and make children more creative in learning. If the teacher is more creative in learning then the child will not experience boredom in learning. Through the creativity of the teacher, the atmosphere of learning in the classroom will be fun. Fun learning process certainly is not created just like that, but the teacher uses learning strategies using media.

This is where the teacher must hone his creativity. The use of media can facilitate teachers in delivering material to children. Learning media can also create interest and arouse children's learning motivation. Ashad (2013: 10) says that learning media is anything that can be used to convey messages or information in the learning process so that it can stimulate students' attention and interest in learning. Furthermore, Gagne and Briggs (1975) (in Arsyad, 2013: 4) explicitly say that learning media includes tools that are physically used to convey the content of teaching materials. From these two meanings, media is a tool used to convey learning material. This tool can be a graphical, visual, 
electronic and audio tool that is used to facilitate information conveyed to children.

The purpose of this research is to make learning in kindergarten more meaningful, enjoyable, and not boring. For that, as teachers we must be able to create creative and innovative learning. Every teacher must be able to think creatively because of a strong urge from within himself to create something new, and the awareness of the importance of something new. The form of teacher creativity in this research is to develop media by modifying the previous media called Busy Book into innovative media called Fun Book Learning, where all the activities inside have been adjusted to the 2013 curriculum for ages 4-5 years.

\section{METHOD}

This research is a type of qualitative research. According to David Williams, 1995 (in Moleong, 2013: 4) qualitative research is collecting data about scientific settings, using natural methods, and conducted by people or researchers who are naturally interested. According to Creswell (2010: 4), qualitative research is methods to explore and understand the meaning that by a number of individuals or groups of people ascribed social or humanitarian problems. Miles and Hubermen (1984), suggested that the activities in qualitative data analysis are carried out interactively and take place continuously until they are finished, so that the data is saturated. The size of data saturation is characterized by no longer obtaining new data or information.

Data analysis in qualitative research at the Dharmawanita Gedangan Kindergarten was carried out since before plunging into the field, at the time of observation, during the implementation of research in the field and after completion of research. The data of this study were obtained from interviews, observations and documentation. Data analysis is done by integrating the data obtained into a category, describing the data into units, analyzing important data, compiling or presenting data in accordance with the research problem in the form of reports and making conclusions so that they are easy to understand.

In accordance with the types of research above, the researchers used an interactive model from Miles and Huberman to analyze the research data. Activities in qualitative data analysis are carried out interactively and take place continuously until it is complete, so that the data is already saturated. The interactive model referred to as follows:

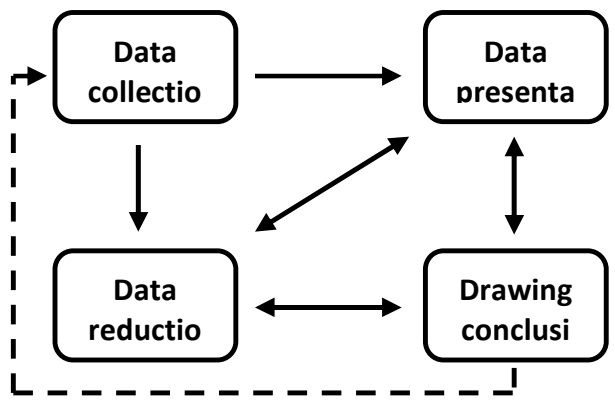

Figure 1. Components of Interactive Model DataAnalysis

Sources: Miles and Huberman (Miles, Huberman and Saldana, 2014: 14)

Before compiling the research instruments used in this study, researchers first create data collection guidelines in advance. Data collection guidelines compiled by researchers are made in the form of tables as follows:

\begin{tabular}{|c|c|c|}
\hline Variable & Aspect & Indicator \\
\hline \multirow{8}{*}{$\begin{array}{l}\text { Teacher } \\
\text { Creativity in } \\
\text { Developing } \\
\text { Originality } \\
\text { learning } \\
\text { media }\end{array}$} & \multirow[t]{2}{*}{ Originality } & $\begin{array}{l}\text { a. Originality in creating } \\
\text { unique media }\end{array}$ \\
\hline & & $\begin{array}{l}\text { b. Originality in creating } \\
\text { different media. }\end{array}$ \\
\hline & \multirow[t]{2}{*}{ Flexibility } & $\begin{array}{l}\text { a. Flexibility in overcoming } \\
\text { obstacles or problems in } \\
\text { developing learning media } \\
\text { Fun Book Learning }\end{array}$ \\
\hline & & $\begin{array}{l}\text { b. Flexibility in utilizing } \\
\text { available materials to make } \\
\text { learning media Fun Book } \\
\text { Learning }\end{array}$ \\
\hline & \multirow[t]{2}{*}{ Smoothness } & $\begin{array}{l}\text { a. Smoothness in generating } \\
\text { ideas / problem solving } \\
\text { towards Fun Book Learning } \\
\text { media }\end{array}$ \\
\hline & & \begin{tabular}{llr} 
b. Smoothness & \multicolumn{2}{c}{ providing } \\
alternative & ways & of \\
developing & Fun & Book \\
Learning media & \\
\end{tabular} \\
\hline & \multirow[t]{2}{*}{ Elaboration } & $\begin{array}{l}\text { a. Elaboration in enriching } \\
\text { and developing Fun Book } \\
\text { Learning media }\end{array}$ \\
\hline & & $\begin{array}{l}\text { b. Elaboration in detailing } \\
\text { the details of the Fun Book } \\
\text { Learning media }\end{array}$ \\
\hline
\end{tabular}

The data validity test in this study was carried out with a triangulation technique that is utilizing something other than data for the purposes of data comparison. Triangulation with data sources is done by comparing data from interviews with observations, what is obtained from observational data with the research situation, views and perspectives of someone with various opinions, and comparing the results of interviews with related documentation.

Data analysis in this research was carried out when data collection was done. Data collection in the form of observation, interviews and documentation. Activities in qualitative data analysis are carried out 
interactively and continued continuously until finished, so that the data becomes saturated. Activities in data analysis, namely data reduction, data presentation, and drawing conclusions / verification, Miles and Huberman (in Sugiyono, 2016: 337)

\section{RESULT AND DISCUSSION}

According to Utami Munandar (2009: 10) the characteristics of creativity can be divided into two, namely cognitive characteristics (talent) and noncognitive characteristics (non-talent). The cognitive characteristics (talent) of creativity consist of:

1. originality,

2. flexibility,

3. fluency and

4. Elaborative.

While the characteristics of non-cognitive creativity include motivation, personality, and creative attitude. Creativity that includes cognitive and non-cognitive characteristics is one of the important potentials to be nurtured and developed.

Based on the results of observations, interviews, and documentation from this study proves that the creativity of Kindergarten Teacher Dharmawanita Gedangan Kutorejo Mojokerto, viewed in terms of originality in creating media in this study is the ability of Kindergarten Dharmawanita Gedangan

Kindergarten teachers to create unique new ideas. The creation is in the form of new works or a combination of existing ones. Creativity is not enough to make something new but a combination of something that already exists. Fun Book Learning is a book made of flannel. The uniqueness of this media can be seen from its name, Fun Book Learning, which means a fun Learning Book. Where in this book there are various kinds of activities especially for children aged 4-5 years. This media is combined from the Busy Book media that previously existed.

Flexibility in overcoming obstacles or problems in making learning media Fun Book Learning. In this case the kindergarten teacher Dharmawanita Gedangan does not have mastery. Incomplete facilities become obstacles for teachers in developing their creativity in overcoming existing obstacles. Flexibility in utilizing available materials to make learning media Fun Book Learning. Because the facilities are inadequate for kindergarten teachers and women, they have to rack their brains to use available materials, for example beads for rework are used as color recognition activity in activity in Fun Book Learning.

Smoothness in generating ideas / problem solving towards Fun Book learning media. According to researchers, ideas generated from the Dharmawanita Gedangan Kindergarten teacher were very creative. Because creative teachers will have sensitive attitudes and initiatives. Creative teachers are one of the factors that influence the quality of education. The results of the observations of researchers, the teacher named Mrs. Dewi looks very deft in making Fun Book Learnig media, from how to provide ideas to create activities from indicators that have been selected according to the 2013 curriculum for ages 4-5 years. For example in KD 1.2 Respect for yourself, others, and the environment as gratitude to God, the idea that comes out is the activity of feeding animals as shown below:

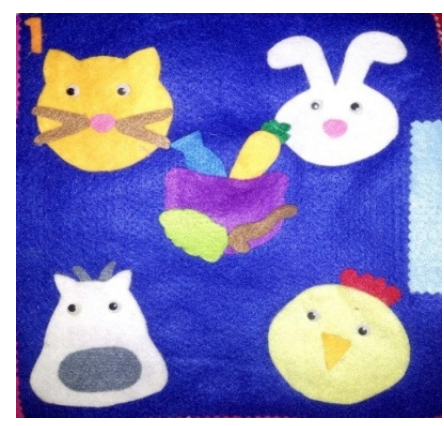

Figure 2. Animal feeding activities

Smoothness in providing alternative ways to develop Fun Book Learning media. In this case the kindergarten teacher Dharmawanita Gedangan is quite good in providing alternatives. Because of limited facilities that make them look for a smooth alternative.

Elaboration in enriching and developing Fun Book Learning media from existing media, namely busy books. Elaboration in this case is detailing all activities in the Fun Book Learning media. From the design concept, the activity material is adjusted to the age of 4-5 years based on the 2013 curriculum. The three Dharmawanita Gedangan Kindergarten teachers namely Mrs. Dewi, Ms. Erma and Mrs. Ati are very enthusiastic in working on the media, due to the strong encouragement to create creative and innovative media.

\section{CONCLUSION}

Based on the results of data analysis shows that the three teachers at the Dharmawanita Gedangan Kindergarten can be said to be creative teachers, because they already have four aspects of creativity, namely fluency in thinking, flexibility, originality, and elaboration. Viewed from the four aspects, his enthusiasm and enthusiasm in developing Fun Book Learning media. They combine from pre-existing media, then all activities are adjusted to the development achievements of children aged 4-5 years of the 2013 curriculum. All of that is done so that their students can get innovative and fun media. 


\section{REFERENCES}

[1] Arsyad, Azhar. 2013. Learning Media. Depok: PT RAJAGRAFINDO PERSADA

[2] Creswell, J. W. (2010). Research design: qualitative, quantitative, and mixed approaches. Yogjakarta: PT Student Library.

[3] Miles, M.B \& Huberman A.M. 1984, Qualitative Data Analysis. Translation by Tjetjep Rohendi Rohidi. 1992. Jakarta: University of Indonesia Publishers.

[4] Miles, M.B, Huberman, A.M, dan Saldana,J. 2014. Qualitative Data Analysis, A Methods Sourcebook, Edition 3. USA: Sage Publications. Translation of Tjetjep Rohindi Rohidi, UI-Press.

[5] Moleong, Lexy J. 2013.

Qualitative Research Methodology.

Bandung: PT Remaja Rosdakarya.

[6] Munandar, Utami. (2009). Developing creativity of gifted children. Jakarta: Rineka copyrighted

[7] Rachmawati, Y. et al. 2011. Creativity Development Strategies in Kindergarten Children. Jakarta: Kencana Media Group.

[8] Santrock, John W., (2008). Educational

Psychology, Second Edition. Jakarta: Kencana.

[9] Sugiyono (2016). Quantitative, Qualitative, and R\&D Research Methods. Bandung: PT Alfabet. 